\title{
2016 年度「日本神経学会賞」応募要項
}

神経内科分野で大学・病院・診療所等に所属し, 研究, 教育, ないし実地診療に積極的に関わり, その発展・ 向上に寄与した方々を顕彰するため, 日本神経学会では 2002 年から学会賞を設けており, 毎年学術大会時 に表彰が行われています。学会賞には学術研究部門, 診療/教育部門の二部門があり, いずれも神経学の発 展にとっては極めて重要です，学術研究部門のみならず，診療/教育部門についても積極的な応募をお願い いたします。

\section{1. 賞の対象および対象者：}

（1）学術研究部門：神経学の学術研究の発展にとくに寄与した学会員，ただし受賞時の年齢が 45 歳以下 であること、

（2）診療/教育部門：神経内科領域の診療あるいは教育の向上にとくに寄与した学会員，ただし年齢は 問いません

2. 提出書類：ご提出いただきました書類については，一切返却できません，

1. 履歴書 : A4 サイズ, 縦長横書き, 12 ポイント。写真添付とともに大学卒業以降の経歴, 賞, 医籍 登録番号, 当学会会員番号, 専門医の場合は専門医番号を記載してください. 団体の場合は代表者 について記載し, 別紙に協力者の氏名, 年齢, 性, 出身大学名, 現在の所属／職位, 当学会会員番号, (専門医番号) の一覧を記載してください（協力者は当学会会員である必要はありません）.

2. 業績内容：A4 サイズ, 縦長横書き, 12 ポイント.

a. 業績課題名：（1）学術研究，（2）診療，（3）教育，の 3 分野から 1 分野を選択してください. 業 績内容が一瞥できる簡単な課題名をつけてください.

b. 業績事由：対象となる業績について, いつ頃から, 何処で, どのような組織で, 何を行ったもの かが概略わかるように記載してください。 また, 研究業績については, その業績の持つ研究分野 での意義と今後の期待される発展，社会的貢献についての評価を，診療／教育業績については, その業績の社会的貢献および今後期待される応用への見込みについての評価を加えてください.

3. 業績目録: $\mathrm{A} 4$ サイズ，縦長横書き，12 ポイント，対象となる業績一覧を「臨床神経学」投稿規定 $\mathrm{E}$ ) 執筆要項 4. 引用文献に準じて記載してください.

4. 推薦書（自薦または他薦）：A4 サイズ, 縦長横書き, 12 ポイント.

5. 添付資料：研究業績については対象となる研究に直接関係する代表的な論文別刷 10 編以内を, 診 療／教育業績については直接の関連資料を，各々 7 部ずつ添付してください (コピー可).

3. 選考方法：選考委員会が選考し，理事会の承認を得ます。選考委員会は代表理事，大会長，前大会長， 編集委員長，診療向上委員長をもって構成します。

4. 発表方法・内容：2016 年 5 月の第 57 回日本神経学会学術大会において表彰し, 賞状および楯を贈呈し ます。表彰時の年度（西暦）の賞と呼ぶものとします。

5. 受賞論文：日本神経学会英文誌「Neurology and Clinical Neuroscience」へ受賞業績をテーマとした論文 をご投稿いただきます。

6. 応募書類送付先 :

一般社団法人日本神経学会

干 113-0034 東京都文京区湯島 2-31-21 一丸ビル

7. 応募期間：2015 年 12 月 18 日（金曜日）必着

一般社団法人日本神経学会 代表理事 高橋 良輔 第 57 回日本神経学会学術大会 大会長 梶＼cjkstart龍兒 


\section{6 年度「樽林賞」応募要項}

日本神経学会は故梘林博太郎先生のご業績を称えて, 錐体外路系の基礎研究分野あるいはそれに関連する疾 患についての優れた研究に対し, 毎年 1 名を選んで樽林賞を贈ります。国籍, 年令, 身分, 資格, 自薦・他 薦は問いません。

\section{1. 賞の対象および対象者：}

錐体外路系の基礎研究分野あるいはそれに関連する疾患についての優れた研究. 国籍, 年齢, 身分, 資格, 自薦・他薦は問いません。

2. 提出書類：ご提出いただきました書類については，一切返却できません.

1. 履歴書：A4 サイズ, 縦長横書き, 12 ポイント。写真添付とともに大学卒業以降の経歴, 受賞歴を記 載してください.

2. 業績内容 : A4 サイズ 2 枚以内, 縦長横書き, 12 ポイント.

a. 業績課題名：業績内容が一瞥できる簡単な課題名をつけてください.

b. 業績事由：対象となる業績について，いつ頃から，何処で，どのような組織で，何を行ったもの かが概略わかるように記載してください. また，その業績の持つ研究分野での意義と今後の期待 される発展, 社会的貢献, 国際的貢献についての評価を加えてください.

3．業績目録：A4 サイズ，縦長横書き，12 ポイント．対象となる業績一覧を「臨床神経学」投稿規定 E) 執筆要項 4. 引用文献に準じて記載してください.

4. 推薦書（他薦の場合のみ必要）：A4 サイズ，縦長横書き，12 ポイント.

5. 添付資料：対象となる業績に直接関係する代表的な論文別刷 10 編以内または資料を，各々 7 部ずつ 添付してください(コピー可).

3. 選考方法：選考委員会が選考し，理事会の承認を得ます，選考委員会は代表理事，大会長，前大会長， 編集委員長, 診療向上委員長をもって構成します。

4. 発表方法・内容：2016 年 5 月の第 57 回日本神経学会学術大会において表彰し, 賞状・楯および副賞を 贈呈します。表彰時の年度 (西暦) の賞と呼ぶものとします。

5. 受賞論文：日本神経学会英文誌「Neurology and Clinical Neuroscience」へ受賞業績をテーマとした論文を ご投稿いただきます。

6. 応募書類送付先 :

一般社団法人日本神経学会

干 113-0034 東京都文京区湯島 2-31-21 一丸ビル

7. 応募期間：2015 年 12 月 18 日（金曜日）必着

一般社団法人日本神経学会 代表理事 高橋 良輔 第 57 回日本神経学会学術大会 大会長 梶龍兒 


\section{第 57 回日本神経学会学術大会のお知らせ}

第57回日本神経学会学術大会 大会長 梶 龍兒

\section{開 催 概 要}

1. 学術大会会期：2016（平成 28）年 5 月 18 日（水） 21 日（土）

「なおる神経内科をめざして」をテーマとして, 上記日程で開催致します。

急速に進歩しつつある技術をふまえて，私たちは臨床・研究において「なおる」神経内科をいかに実践 していくかを皆様とともに考えたいと思います。

またサブテーマとして「わかる神経内科」をもうけ教育企画も充実させております。

2. 学術大会会場：神戸コンベンションセンター (神戸国際会議場・神戸国際展示場)

干 650-0046 神戸市中央区港島中町 6-9-1（国際会議場）

干 650-0046 神戸市中央区港島中町 6-11-1（国際展示場）

神戸ポートピアホテル

干 650-0046 神戸市中央区港島中町 6 丁目 10-1

3. 演題募集期間： 2015 年 10 月 5 日（月）正午 12 月 2 日（水）正午 ※募集期間の延長はありませんのでご注意ください.

4. 事前参加登録：2016 年 2 月初旬開始予定

※事前参加登録はすべてオンラインにより登録を行います。

※日本神経学会第 7 回専門医育成教育セミナー, 第 13 回生涯教育セミナー「レクチャー」「Hands-on」,

第 4 回メディカルスタッフ教育セミナー, 教育コース, 及び各種共催セミナー（モーニングセミナー, ランチョンセミナー，イブニングセミナー，プレミアムイブニングセミナー）もオンラインによる事 前登録制とする予定です。

※詳細は追ってホームページでご案内いたします。（http://www.neurology-jp.org/sokaitiho/neuro2016/）

5. 参加費 :

\begin{tabular}{|c|c|c|c|}
\hline & & 事前 & 当日 \\
\hline \multirow[b]{2}{*}{ 会 } & 正会員 & 15,000 円 & 18,000 円 \\
\hline & 研修医会員 & 3,000 円 & 3,000 円 \\
\hline \multirow[t]{2}{*}{ 員 } & 学生会員（大学院生） & 3,000 円 & 3,000 円 \\
\hline & 学生会員（学部学生） & 無料 & 無料 \\
\hline
\end{tabular}

\begin{tabular}{|c|c|c|c|c|}
\hline & & & 事前 & 当日 \\
\hline \multirow{7}{*}{$\begin{array}{l}\text { 非 } \\
\text { 会 } \\
\text { 員 }\end{array}$} & \multicolumn{2}{|l|}{ 非会員（医師） } & 18,000 円 & 21,000 円 \\
\hline & \multicolumn{2}{|l|}{ 非会員（協賛企業社員） } & 18,000 円 & 21,000 円 \\
\hline & メデイカルスタッフ & $※ 1$ & 5,000 円 & 5,000 円 \\
\hline & \multicolumn{2}{|l|}{ 大学院生 - 初期研修医 } & 3,000 円 & 3,000 円 \\
\hline & \multicolumn{2}{|l|}{ 海外からの参加者 } & - & 3,000 円 \\
\hline & Travel Grant 受賞者 & $※ 2$ & - & 3,000 円 \\
\hline & \multicolumn{2}{|l|}{ 学部学生 · 国内留学生 } & 無料 & 無料 \\
\hline
\end{tabular}

※ 15 月 21 日（土）のメディカルスタッフ教育セミナーのみにご参加のメディカルスタッフは, 参 加費 1,000 円で，当日（21日）の他のプログラムも聴講が可能です.

※2 Travel Grantに採用された方が対象となります。

〈Travel Grantについて〉

○下記の方を対象に，Travel Grant を支給いたします。

・海外の神経内科医および研修医（上限 10 万円（国ごとに上限金額が異なります.））

・日本に留学中の神経内科医掞よび研修医（上限 5 万円とし，往復交通費実費程度を支給予定） 
○抄録の提出が必須となっております.

ご希望の方は，第 57 回日本神経学会学術大会ホームページよりご登録ください.

○年齢制限はございません.

○対象の演題を会場で発表することが支給の条件となります。代理受け取りや，ポスターを貼るだけ， という場合は Grant 支給の対象となりませんのでご注意ください.

※詳細は追ってホームページでご案内いたします。（http://www.neurology-jp.org/sokaitiho/neuro2016/）

6. 託児所：会期中に託児所をご用意いたします。お申し込み方法などにつきましては，追ってホームぺー ジでご案内いたします。（http://www.neurology-jp.org/sokaitiho/neuro2016/)

7. エクスカーション：会期中エクスカーションを企しております。お申込み方法等につきましては, 追ってホームページでご案内いたします。（http://www.neurology-jp.org/sokaitiho/neuro2016/)

8. お問い合わせ :

【大会長校事務局】

徳島大学大学院医歯薬学研究部医学部門内科系臨床神経科学分野

干 770-8503 徳島市蔵本町 3 丁目 18-15

【日本神経学会事務局】

干 113-0034 東京都文京区湯島二丁目 31 番 21 号一丸ビル

TEL : 03-3815-1080 FAX : 03-3815-1931

【第 57 回学術大会運営事務局】

干 102-8481 東京都千代田区麹町 5-1 弘済会館ビル 株式会社コングレ内

TEL : 03-5216-5318 FAX : 03-5216-5552

E-mail : neuro57@congre.co.jp

\section{一般演題について}

口演発表とポスター発表を予定しております。

1. 申し込み：申し込みはすべてオンラインにて受け付けます.

2. 演題募集期間： 2015 年 10 月 5 日（月）正午〜 12 月 2 日（水）正午 ※募集期間の延長はありませんので，ご注意ください.

\section{3. 演題要旨作成時の注意}

（1）演題の制限： 1 演者につき 1 題にします。ただし，共同演者になることは差し支えありません。一 施設から多数の申し込みも歓迎いたします。

(2) ご登録いただく項目

○登録・発表言語：日本語もしくは英語（応募カテゴリーによる言語指定あり）

※原則，抄録ご登録言語が発表言語となるようにセッションを組む予定です。

○発表形式区分：口演もしくはポスターより選択

○筆頭演者と共同演者の氏名（日英）：演者数は 20 名以内

○筆頭演者と共同演者の所属機関（日英）：所属機関数は 10 機関以内

○演題名（日英）：日本語は全角 40 文字以内，英語は半角 80 文字以内

○演題抄録：

・抄録は，日本語または英語でご登録ください。（応募カテゴリーによる言語指定あり）

・日本語は全角 800 文字以内，英語は半角 1,600 文字以内とします.

・【目的】,【方法】、【結果】、【結論】に分けて簡潔に記入してください、その都度改行はしない でください，改行を行っても，抄録印刷の際に反映されません.

・抄録内容が不完全な場合（誤字, 脱字, 具体的な数值の不足, 【目的】, 【方法】, 【結果】, 【結論】 に項目立てされていないなど），不採用になりますので抄録作成の際に細心の注意を払ってご 投稿ください.

○動画の有無：ポスター発表として採択された場合に「動画あり」を選択された方には，ポスター パネルに，動画 URLのQR コードをお貼りいただけます。

（3）筆頭演者は本学会の会員である必要があり，登録時に会員番号およびパスワードを入力していただ きます，未入会者は登録前に必ず入会申請を行い，入会手続きをお取りください. 2015 年 12 月 2 
日（水）正午までにご入会手続きが完了していない場合はご登録いただいた演題を不採択とさせて いただく場合がございますので，ご了承ください.
日本神経学会事務局
干 113-0034 東京都文京区湯島 2-31-21 一丸ビル 2 階
TEL：03-3815-1080 FAX:03-3815-1931 （受付時間：平日 10:00 17:00）

（4）応募演題の研究の内容により，厚生労働省等による倫理指針（臨床研究，ヒトゲノム・遺伝子解析 研究, 疫学研究, ヒト幹細胞を用いる臨床研究など）及び所属 施設が定めた倫理規定（動物実験 等を含む) を遵守すると共に，あらかじめ所属施設等に揖いて倫理審査委員会等による審査・承認 を得ていることが必要です。詳細は学会ウェブサイトにある「日本神経学会学術大会時の演題の倫 理面について」(http://www.neurology-jp.org/gaiyo/pdf/endai_rinri.pdf) をご覧ください.

（5）演題の査読を行いますので, 演題名や抄録本文の中で, 所属機関が明らかになるような記述や, 筆 頭著者や共著者が明らかになるような記述（謝辞を含む）は避けてください．

（6）薬品名を記載する場合は，必ず一般名を記載してください.

（7）一般演題の一例報告については原則認めません。 ただし, 症候学的, 学術的な面などから深く検討 されている内容であれば，審議の上採択する場合が有ります。

（8）患者の個人情報に抵触する可能性のある内容は, 患者あるいはその代理人からインフォームド・コ ンセントを得た上で，個人が特定できないよう十分留意して発表してください．入院年月日や年齢 など，個人が特定される恐れのある情報を含む発表は禁止します。

（9）第 57 回日本神経学会学術大会最優秀賞を設けますので，抄録登録時にご申請ください，応募資格は, 登録時, 学部卒業後 15 年未満とします。正会員に限らず, 学生会員および研修医会員も応募可能です.

（10）演題登録締め切り後の登録内容の修正は一切承りませんので注意深く抄録をご準備ください. 抄録 が採択された場合, 事務局からの修正依頼もございません。また学術大会終了後の修正も承りませ んのでご了承ください.プログラム・抄録集の“抄録集”部分が「臨床神経学サプリメント号」と して認定されております。掲載ページには「臨床神経学 56 巻サプリメント号 S- ○○」という頁 数が付与されます。

4. 利益相反の開示について

産学連携による臨床研究の適正な推進を図り, 科学性・倫理性を担保に遂行された臨床研究成果の発表 における中立性と透明性を確保するため, すべての発表者に「利益相反 (Conflict of Interest, COI と略 す)」の開示を求めることになっております.

演題登録画面の「利益相反」の入力欄にて「あり」「なし」をご選択ください。「あり」の場合, 演題登 録後に日本神経学会 WEB サイトの所定ページより「COI 自己申告書様式」をダウンロードいただき, ご記入の上，書留にて下記まで送付してください，提出締切：2015 年 12 月 10 日（金）必着

\section{COI 自己申告書付送先}

113-0034 東京都文京区湯島 2-31-21 一丸ビル

日本神経学会事務局 57 回大会 COI 受付係

TEL:03-3815-1080 FAX:03-3815-1931

なお，利益相反について，専門的な内容に関するご質問は上記学会事務局までお問合せください．

5. 採否通知

演題登録完了通知メールに記載されている 7 ケ夕の登録番号を以て, 2016 年 2 月中旬頃より, 大会ウェ ブサイトの採択演題一覧ページにて公開いたします。個別にメールでの発表日時などの通知は致しませ んので, 必ず大会ウェブサイトをご確認ください.

6. 口演による発表方法

(1) PC プロジェクターが使用可能です.

（2）ビデオプロジェクターの使用はできませんが，PCからの動画投影は可能です.

（3）発表データはメディア（USBメモリーまたは CD-R）での持ち込みとなります。ただし動画がある 場合にはご自身のPCをご持参ください.

（4）研究倫理諸規定および個人情報保護の諸規定に遵守してご発表ください.

（5）利益相反の開示についてのスライドをご提示いただきます。詳しくは日本神経学会ホームページの 「学会概要」内, 「定款・規則」をご参照ください.

（6）学術大会の国際化のため，口演スライドはできるだけ英語で作成するようお願いいたします。ただ し，英語セッションにおいては，口演スライドは必ず英語で作成してください. 


\section{7. ポスター形式による発表方法}

（1）展示パネルは縦 $210 \mathrm{~cm} \times$ 横 $90 \mathrm{~cm}$ の予定です。パネル上部の演題番号のみ, 学術大会事務局で用 意いたします，演題・所属・氏名（簡単に）は各自で $20 \mathrm{~cm} \times 70 \mathrm{~cm}$ に横書きしてください.

（2）ポスターは要旨・目的・方法・結果・考察の順に大きくわかりやすく書いてください. 文章は 2 $3 \mathrm{~m}$ 離れたところからでも見えるような大きなポイント文字を使い, 図式は一辺が $20 \mathrm{~cm}$ 以上の大 きさでタイトル・簡単な説明をつけてください.

（3）演題登録時に「動画あり」にチェックをされた方は，ポスターパネル上の指定スペースに，動画 URLの QR コードをお貼りいただけます。QR コード準備方法の詳細は後日ウェブサイトに揭載い たします。

（4）パネル自体に直接文字や図表を書いたり，パネルに糊づけしたりはできません.

（5）ポスターをパネルに貼りつけるための画鋲は会場に用意いたします.

（6）ポスター発表のスケジュール等は演題採用通知を発表後にご案内させていただきます.

（7）研究倫理規定および個人情報保護の諸規定を順守してご発表ください.

（8）利益相反の開示についての内容を記載してください。詳しくは日本神経学会のホームページ「学会 概要」内, 「定款・規則」をご参照ください.

（9）学術大会の国際化のため，ポスターはできるだけ英語で作成するようお願いいたします。ただ， 英語セッションにおいては，ポスターは必ず英語で作成してください，

8. 日本神経学会 学術大会運営委員 (50 音順・敬称略)

\begin{tabular}{|c|c|c|c|c|c|c|c|c|c|c|c|}
\hline $\begin{array}{l}\text { 阿部 } \\
\text { 佐々 }\end{array}$ & $\begin{array}{l}\text { 康二 } \\
\text { 秀直 }\end{array}$ & $\begin{array}{l}\text { 宇川 } \\
\text { 鈴木 }\end{array}$ & $\begin{array}{l}\text { 義一 } \\
\text { 則宏 }\end{array}$ & $\begin{array}{l}\text { 梶 } \\
\text { 高橋 }\end{array}$ & $\begin{array}{l}\text { 龍兒 } \\
\text { 良輔 }\end{array}$ & $\begin{array}{l}\text { 加世 } \\
\text { 辻 }\end{array}$ & $\begin{array}{l}\text { 日ゆ子 } \\
\text { 省次 }\end{array}$ & $\begin{array}{l}\text { 吉良 } \\
\text { 西澤 }\end{array}$ & $\begin{array}{l}\text { 潤一 } \\
\text { 正豊 }\end{array}$ & $\begin{array}{l}\text { 楠 } \\
\text { 水澤 }\end{array}$ & $\begin{array}{r}\text { 進 } \\
\text { 英洋 }\end{array}$ \\
\hline 第 57 & 回日才 & 学会学 & 術大会 & 年次学術 & 大会学 & 員（5 & 音順 · & 尔略） & & & \\
\hline 饗場 & 郁子 & 青木 & 正志 & 赤松 & 直樹 & 飯塚 & 高浩 & 石浦 & 浩之 & 石川 & 欽也 \\
\hline 尹東 & 秀文 & 伊藤 & 義彰 & 井上 & 治久 & 今井 & 富裕 & 宇川 & 義一 & 漆谷 & 直 \\
\hline 小栗 & 卓也 & 柿田 & 明美 & 加世巨 & けゆみ子 & 勝野 & 雅央 & 亀井 & 聡 & 川井 & \\
\hline 井 & 俊孝 & 神田 & 隆 & 桑原 & 聡 & 古和 & 久典 & 齊藤 & 祐子 & 坂本 & \\
\hline 條 & 伸夫 & 下畑 & 享良 & 下濱 & 俊 & 鈴木 & 重明 & 園生 & 雅弘 & 高橋 & 一司 \\
\hline 名橋 & 祐二 & 立花 & 直子 & 德丸 & 阿耶 & 富本 & 秀和 & 永井 & 義隆 & 中島 & 一郎 \\
\hline 中島 & 健二 & 中根 & 俊成 & 西川 & 典子 & 西野 & 一三 & 西山 & 和利 & 野寺 & 裕之 \\
\hline 間 & 敬憲 & 長谷川 & |一子 & 服部 & 信孝 & 羽生 & 春夫 & 原 & 元彦 & 樋口 & 真人 \\
\hline 田 & 幸一 & 松井 & 尚子 & 松原 & 悦朗 & 松本 & 昌泰 & 松本 & 理器 & 丸山 & 博文 \\
\hline & 園子 & 宮井 & 一郎 & 宮地 & 隆史 & 村田 & 美穂 & 目崎 & 高広 & 望月 & 秀棈 \\
\hline & 正仁 & 山中 & 宏二 & 山村 & 隆 & 横田 & 隆徳 & 吉井 & 文均 & 渡辺 & \\
\hline
\end{tabular}

和泉 唯信 (事務局)

10. 学術大会教育プログラムワーキンググループ（50 音順・敬称略）

安東由喜雄 和泉 唯信 犬塚 貴 梶 龍兒

園生 雅弘服部 信孝

\section{各種企画のお知らせ}

\section{1. 大会長講演}

梶龍兒 (徳島大学大学院医歯薬学研究部医科学部門内科系臨床神経科学分野 教授)

2. Plenary Lecture (予定)

Stanley Fahn（The Neurological Institute of New York, Columbia University Medical Center)

3. 特別講演：2015 年度学会賞・樽林賞受賞者招待講演

2015 年度学会賞（学術研究部門）：小野賢二郎（金沢大学附属病院神経内科）

2015 年度学会賞（診療部門）：橋本洋一郎（熊本市民病院神経内科）

2015 年度楢林賞：貫名 信行 (同志社大学大学院脳科学研究科認知記憶加齢部門)

4. Semi-Plenary Lecture (予定)

日野原重明（聖路加国際病院名誉院長）

5. Neuroscience Frontier Symposium（予定） 
6. East Asian Neurology Forum 関連プログラム（予定）

7. 各種シンポジウム（予定）

8. レクチャーマラソン（予定）

9. 教育コース（事前登録制：予定）

10. メディカルスタッフポスターセッション（予定）

11. 医学生・初期研修医セッション（予定）

12. 各種共催セミナー (予定)

13. 神経内科ウィーク（市民公開講座・予定）

14. 日本神経学会第 13 回生涯教育セミナー「レクチャー」(5月18日（水）・21日（土）（予定）

15. 日本神経学会第 13 回生涯教育セミナー「Hands-on」（5 月 18 日（水）・21日 (土)）(予定)

16. 日本神経学会第 7 回専門医育成教育セミナー (5 月 18 日 (水)) (予定)

17. 日本神経学会第 4 回メディカルスタッフ教育セミナー（5 月 21 日（土）（予定）

18. 日本神経学会市民講座（5月22 日（日））（予定）

19. 脳梗塞 rt-PA 適正使用講習会（予定） 


\title{
2015 年度（第 41 回）日本神経学会神経内科専門医試験のご報告
}

\author{
日本神経学会 代表理事高橋良輔 \\ 同 専門医認定委員会 委員長 中島健二
}

2015 年度試験は，6月 13 日（土）に一次試験， 7 月 11 日（土）に二次試験を実施し, 最終的に以下 の 204 名を日本神経学会専門医試験の合格者として認定致しました。

本試験の実施にあたり，試験問題作成，試験監督，症例サマリーの査読および面接試験にご協力をい ただいた方々のお名前を以下に揭げ，御礼に代えさせていただきます。

\section{5 年度日本神経学会専門医試験合格者：}

\begin{tabular}{|c|c|c|c|c|c|c|c|c|}
\hline 秋 & 拓 也 & 上 野 & 莉 & 河 野 & 友 裕 & 鈴 & 木 & 淳 \\
\hline 浅 & 洋 平 & 植 村 & 順 & 河 & 聡 & 鈴 & 木 & 理 \\
\hline 田 & 真 士 & 打 田 & 佑 & 川 & 雄 & 鈴 & 山 & 耕 \\
\hline 部 & 鉄 也 & 梅 村 & 想 & 川 & 美 & 園 & 田 & 啓 \\
\hline 野 & 朋 & 江 原 & 祥 & 岸 & 祥 & 高 & 木 & 隆 \\
\hline 野 & 優 & 遠 & 芳 & 北 薗 & 久 & 高 & 谷 & 美 \\
\hline 川 & 修 治 & 大 井 & 和 & 北 & 太 & 高 & 野 & 雅 \\
\hline 木 & 信 之 & 大 石 & 真莉子 & 木 & 聡 & 滝 & 澤 ～～ & 歩 \\
\hline 藤 & 孝 志 & 大 浦 & 一 雅 & 木 村 & 有 希 & 澈 & 瀬 & 康 \\
\hline 藤 & 匡 宏 & 逢 坂 & 麻由子 & 久米本 & 貴 & 瀧 & 田 & \\
\hline 國 & 洋一郎 & 大 橋 & 信 彦 & 小 出 & 瑞 穂 & 田 & $\square$ & 宗 \\
\hline 泉 & 㻟 矢 & 奥 住 & 文 & 高 & 紀 & 武 & 内 & 俊 \\
\hline 岡 & 桂 & 小 & 明 & 高 & 純 & 武 & 田 & 芳 \\
\hline 狩 & 龍 & 尾 澤 & 一 & 小 & 麻 & 田 & 島 & 和 \\
\hline 田 & 真 & 乙 宗 & 宏 範 & 近 & 総 & 田 & 尻 & 佑 \\
\hline 田 & 知 雅 & 小野原 & 亜希子 & 近 & 円 香 & 伊 & 達 & 悠 \\
\hline 井 & 淳 子 & 小 畑 & 馨 & 齋 藤 & あかね & 田 & 中 & 寛 \\
\hline 上 & 晃 & 小 & 啓 & 齊 & 麻 美 & 田 & 中 & 裕 \\
\hline 川 & 英 & 梶 & 誠 & 齋＼cjkstart藤 & 充 & 田 & 中 & 陽 \\
\hline 川 & 裕 一 & 堅 & 慎 & 佐々木 & 拓 & 谷 & 岡 & 洸 \\
\hline 市野瀬 & 慶 子 & 加 & 貴 & 佐 & 和 & 田 & 野 & 大 \\
\hline 五 影 & 昌 & 加 & 隼 康 & 佐 & 悠 & 玉 & 木 & 良 \\
\hline 藤 & 大 & 加 & 奈津子 & 佐 & 謙 & 俵 & & \\
\hline 石 & 佳 & 金 & 哲 也 & 佐 & 正 & 千 & 葉 & 隆 \\
\hline 井 & 和 & 金 & 雅 & 澤 & 正 典 & 津 & 崎 & 光 \\
\hline 村 & 友 & 金 & 智 & 島 & さゆり & 辻 & & 佑入 \\
\hline 城 & 寛 & 狩 & 允 & 清 & 高 弘 & 辻 & 井 & 智 \\
\hline 澤 & 絵 & 神 & 久 & 下 & 怜 & 土 & 田 & 剛 \\
\hline 波 & 弘 & 河 & 滋 & 城 & 崇 之 & 角 & 田 & 由 \\
\hline 波 & 正 興 & 河 & 真 & 菅 & 恵梨子 & 鶴 & 岡 & \\
\hline 岩 原 & 直 敏 & 川 添 & 僚 也 & 杉 & 慎太郎 & 同 & 道 & 頼 \\
\hline
\end{tabular}




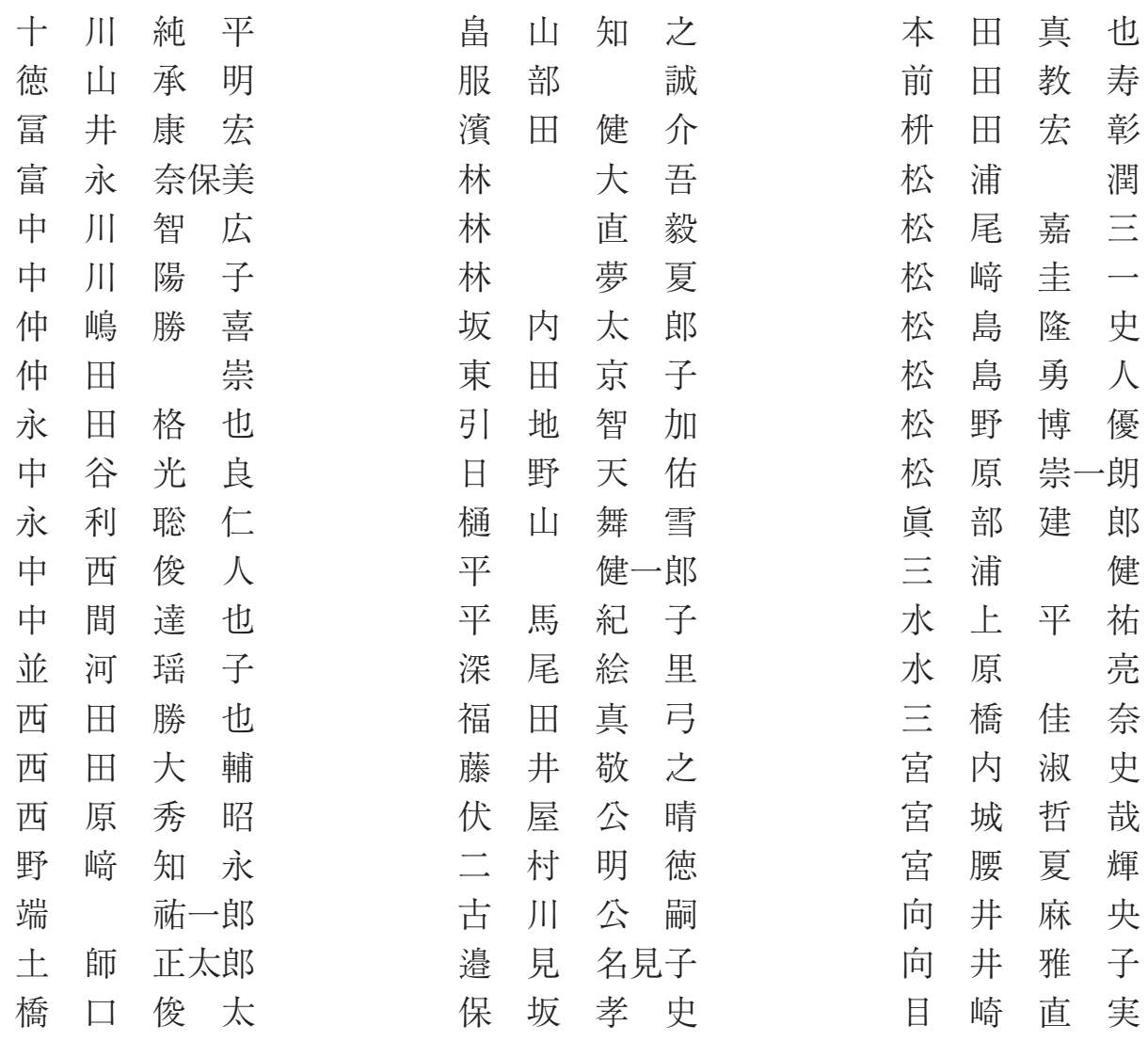

安井昌彰

柳 橋優

柳 原 由 記

柳 本 祥三郎

山岸裕子

山下和哉

山田剛平

山田萌美

山本詞子

吉田幸司

吉田俊一

吉田有 佑

吉 永 健 二

吉 本 武 史

米川 智

渡辺慶介

渡利茉里

以上 204 名

（50 音順 - 敬称略）

\section{5 年度日本神経学会専門医試験にご協力をいただいた方々：}

\begin{tabular}{|c|c|c|c|c|c|c|c|c|c|c|c|c|}
\hline 青 木 & 正 志 & 岩 崎 & 泰 & 雄 & 片 & 山 & 隆 & 行 & \multicolumn{3}{|c|}{ 小松本 } & 悟 \\
\hline 赤 松 & 直 & 上 野 & & 聡 & 加 & 藤 & 丈 & 夫 & 古 & 和 & 久 & 典 \\
\hline 朝比奈 & 正 & 魚 住 & 武 & 則 & 金 & 藤 & 大 & 三 & 近 & 藤 & 正 & 樹 \\
\hline 阿 部 & 康 二 & 宇 川 & 義 & 一 & 亀 & 井 & & 聡 & 坂 & 井 & 利 & 行 \\
\hline 井 & 啓 & 宇 高 & 不可 & 丁思 & 亀 & 山 & & 隆 & & 木 & 秀 & 直 \\
\hline 木 & 俊 彦 & 内 & 俊 & 記 & 川 & 井 & & 充 & 佐 & 藤 & & 晶 \\
\hline 東 & 由喜雄 & 槍 & 公 & 明 & 川 & 村 & 眞 & 弓 & 四 & 方 & 裕 & 子 \\
\hline 五十嵐 & 修 一 & 宇 & & 正 & 菅 & & 信 & 一 & 清 & 水 & & 閏 \\
\hline 井口 & 保 & 大 & 智 & 彦 & 苅 & 田 & 典 & 生 & 下 & & 泰 & 司 \\
\hline 田 & 昭 & 大 島 & & 淳 & 神 & 田 & & 隆 & 下 & 濱 & & 俊 \\
\hline 田 & 賢 & 大 野 & & 司 & 北 & 川 & 一 & 夫 & 東 & 毎林 & 幹 & 夫 \\
\hline 田 & 修 & 岡 & 尚 & 省 & 北 & 川 & 泰 & 久 & 神 & & 一 & 敬 \\
\hline 田 & 佳 & 岡 本 & 浩一 & 一郎 & 木 & 村 & 和 & 美 & 新 & 野 & 正 & 明 \\
\hline 垣 & 景 & 小野寺 & & 理 & 吉 & 良 & 潤 & 一 & 杉 & 浦 & 嘉 & 泰 \\
\hline 藏 & 礼 & 小 宅 & 睦 & 郎 & 金 & 野 & 竜 & 太 & 鈴 & 木 & 則 & 宏 \\
\hline 川 & 博 & 織 & 智 & 之 & 日 & 下 & 博 & 文 & 鈴 & 木 & $ゆ$ & \\
\hline 東 & 秀 & 海 & 賢 & 一 & 楠 & & & 進 & 砂 & 田 & 芳 & 秀 \\
\hline 塚 & 貴 & 柿 & 明 & 美 & 桑 & 原 & & 聡 & 仙 & 石 & 錬 & 平 \\
\hline 今 井 & 啓 輔 & 梶 & 龍 & 兒 & 幸 & 原 & 伸 & 夫 & 園 & 生 & 雅 & \\
\hline
\end{tabular}




\begin{tabular}{|c|c|c|c|c|c|}
\hline 高 木 & 誠 & 豊 島 & 至 & 平 田 & 幸 \\
\hline 嶋 & 博 & 豊 & 則 & 平 & 照 \\
\hline 瀬 & 敬一郎 & 長 & 彦 & 平 & 幹 \\
\hline 橋 & 牧 郎 & 中 & 法 & 福 & 俊 \\
\hline 橋 & 正 & 中 & 一 郎 & 福 & 敏 \\
\hline 橋 & 良 & 中 島 & 二 & 藤 & 信 \\
\hline 山 & 嘉 & 中 嶋 & 秀 & 舟 & \\
\hline 田 & 景 & 永 田 & 栄一郎 & 古 & 英 \\
\hline 田 & 克 & 中 原 & 登志樹 & 古 谷 & 博 \\
\hline 花 & 久 & 中 村 & 慎 一 & 法化図 & 陽 \\
\hline 中 & 惠 子 & 中 村 & 作 & 本 田 & 治 \\
\hline 中 & 耕太郎 & 中 村 & 彦 & 牧 & 邦比 \\
\hline 中 & 章 景 & 中 & 幸 & 松 & \\
\hline 中 & 真 & 永 山 & 雄 & 松 & 秀 \\
\hline 橋 & 紀 & 新 美 & 紀 & 松 & 悦 \\
\hline 脇 & 考 & 西 澤 & 豊 & 松 & \\
\hline 岡 & 晃 & 西 & 三 & 松 & 美由走 \\
\hline 葉 & 厚 & 西 & 利 & 松 & 英 \\
\hline 葉 & 進 & 野 川 & 茂 & 松 & 昌 \\
\hline 辻 & 省 & 野 村 & 恭 一 & 三 & 健 \\
\hline 井 & 義 & 野 村 & 志 & 三 & 園 \\
\hline 田 & 清 & 野 元 & 正 弘 & 水 & 英 \\
\hline 山 & 靖 & 橋 本 & 隆 男 & 水 & 敏 \\
\hline 勇 & 学 & 橋 本 & 洋一郎 & 溝 & 雅 \\
\hline 登木口 & 進 & 長谷川 & 隆 文 & 南 & 正 \\
\hline 戸 田 & 達 & 長谷川 & 弘 & 宮 & 裕 \\
\hline 松 & 省 & 服 部 & 信 孝 & 宮 & \\
\hline 本 & 秀 & 林 & 由起子 & 宮 & 隆 \\
\hline 山 & 誠 彦 & 原 & 英 夫 & 宮 & 智 \\
\hline
\end{tabular}

武 藤 多津郎

村上秀 友

村 田 美 穂

村松和浩

村山繁 雄

望 月 秀 樹

望月仁志

本 村 政 勝

森悦 朗

安井敬 三

山尾房 枝

山口修平

山田猛

山田正仁

山中義崇

山野井 貴 彦

山本達也

横田隆徳

吉井文均

芳川浩男

吉田一人

米田行宏

若 林 孝一

脇 田英 明

渡辺浩之

渡邊嘉之

以上 189 名

（50 音順 - 敬称略）

来年の 2016 年度（第 42 回）日本神経学会専門医試験は, 第一次試験を 2016 年 6 月 11 日（土）に 東京大学駒場キャンパス，第二次試験を 2016 年 7 月 9 日（土）に日本都市センター会館にて実施する 予定です。

面接試験などに改めてご協力を宜しくお願い致します. 


\section{5 年度（第 41 回）日本神経学会神経内科専門医試験＼cjkstart講評}

第 41 回日本神経学会神経内科専門医試験における筆記試験・面接試験では 204 名が合格し, 新規受験者 の合格率は $83.1 \%$ でした。

筆記試験では必修, 一般, 症例の 3 領域に分けてそれぞれ 100 題を出題し, 必修問題はより高い正答率を 求めています。症例サマリー 10 例についての査読も行われ, 不適切と判定されたサマリーは修正・再提出 をして頂き, 面接試験に反映されています。ささらに, 指導医による研修内容の評価も必要としています。

1. 筆記試験について

今年の一次試験においては試験問題の落丁がありました。大きなラブルにはならなかったと考えていま すが，若干なりとも影響を受けた受験生の方々には申し訳なく，専門医認定委員会としてお詫び致します。 落丁の発生防止に向けて検討し, 問題作成段階での再発防止について確認しました。筆記試験を開始する際 に受験生の方々にもまず落丁の有無を確認して頂くようにアナウンスしておりますが, 各段階で落丁の有無 確認を行い，落丁の発生防止を徹底していくようにしたいと考えています.

1）正答率が低かった領域

全体として正答率の低かった領域は，末梢神経，筋・神経筋接合部の領域でした。末梢神経や筋の病理学 的検査において，生標本を読む経験が少ないように思われます。それぞれの病理学的所見を示す疾患のみな らず,それらの所見がどういう原因で起こるのかといったことまで理解するようにして頂きたいと考えます。 筋疾患は現在の研修で遭遇する機会が少ないかとも思われますが, 治療可能となってきた疾患も少なくな く，そういった観点からも，進歩している治療法を含めた筋疾患の理解に務めて頂きたい.

2）正答率が比較的高かった領域

血管障害, 救急 ·外傷, 脱髄・免疫, 春椎 ·春髄の領域は, 比較的良く研修が行われていると推定されま した。しかし，急性期のみならず，その後のリハビリを含め，臨床医として知っておくべき医療・福祉・介 護, 地域連携などの制度, その適応についての理解が不足しているようにみられました。他職種に任せっき りにするのではなく, 患者の療養環境なども把握し, 他職種などとの十分な連携と共に, 時には指導・助言 を行うことも神経内科医に求められていることを理解して頂きたいと考えます.

入院診療で受け持つ機会が多くなっていると考えられる脱髄・免疫性疾患についての理解は比較的良好の ように思われましたが, 背景にある基礎的な知識などの神経科学としての知識も学ぶ姿勢を望みたいと考え ます。

脊椎・春髄疾患についての理解も全体的に深まってきているように思われましたが，遭遇する機会の多い 頸椎症性脊髄症のレベル診断に関する理解が不十分であると思われました.

3）その他の領域

画像と脳部位を含めた臨床解剖, 神経心理に関する問題は，ある程度の理解がされていると思われました，

また，日常診療で用いる神経生理検査の基本的な事項は理解しておいて頂きたいと考えます.

神経変性疾患の領域は比較的良く勉強されていると思われましたが, 治療に用いられる薬剤の副作用につ いての知識が若干不足している傾向も見られました。ぜひ理解を深めておいてほしいと考えます。

認知症を有する高齢者は急増しており，必ずしも認知症自体を診療対象としていない急性期疾患医療にお いても認知症を有する方を診療する機会は多く，他領域スタッフなどへの助言を求められる場合も少なくあ りません。神経内科専門医には変性性の認知症疾患の鑑別診断も期待されており, その知識は十分に持つよ うにして頂きたい。また，薬剤による認知症症状の増悪についても臨床において直面することは多く，それ らの知識も重要です.

感染症・炎症領域の基本的な知識が必ずしも十分でない傾向も見られました。治療可能な疾患が多い領域 であり，基本的な事項は正確に学んでおいて頂きたい。

日常診療において診る機会が多い,てんかんの種々の発作型の理解が十分でないように思われました.

なお，日本神経学会が発行しています診療ガイドラインなども，ぜひ目を通しておいて頂きたいと考えます。

4）比較的正答率の低かった設問について

必修問題では，下肢の negative myoclonusの診かたの具体的手技，各種の不随意運動の表面筋電困記録に おける特徵, 中枢神経病理における肉眼所見の理解, 細菌性髄膜炎の症状・症候などの基本的な事項, 筋生 検や生検筋の病理, 組織化学の染色法, 女性てんかん患者における診療上の注意などが低い正答率の設問で した。 
一般問題では，錐体路障害で出現する症候の診かた，認知症患者におけるは排尿障害治療薬などの高齢者 医療に関連する薬剤の知識, 単純へルペス脳炎の画像, 我が国に広く分布しているツッガムシ病の基本的な 事項, 中枢ミエリンの構成, 実地臨床においてみるてんかん発作型とその背景病態などが低い正答率でした. 症例問題においては, 記憶の分類, アルコール性ニューロパチー, FAP1 型, CIDP などの感覚障害の特徵, 付随する症候, 認知症の背景病態, 孤発性遅発性ネマリンミオパチー, 群発頭痛や発作性片側頭痛といった 比較的頻度の少ない頭痛は低い正答率でした。

なお，症例問題においては，末梢神経の領域を中心に問題文が十分に読みこまれていないのではないかと 思われる解答が目立ちました。鑑別する際の肯定，あるいは，否定していくための確認事項など，記載され ている経過や臨床所見などの意味を考えて問題を解くようにして頂きたいと考えます.

2. 面接試験についての面接員からの意見

基本的な神経学的診察手技はできる受験生が多くなっており，神経診察法のビデオやハンズオンなどの効 果もあるのではないかとの指摘もありました。一方，まだ基本的な手技をマスターしていないと判断される 受験生もあり，神経診察法は神経内科専門医の基本であることを改めて認識して勉強して頂きたいと考えま す。また，基本的な診察法はできるが，応用的な診察法，判断に苦慮する場合の診察法や対応・工夫などに 欠けているとの指摘もあり, 神経内科専門医にふさわしい神経診察の技量の取得にも取り組んで頂きたいと 考えます，研修指導責任者の先生方には一層の研修指導をお願いしたいと考えます。

経験症例の領域に偏りがある受験生が少なくないとの指摘もありました．急性期診療のみの診療施設で研 修してきた受験生の中には処置や治療に急ぐ習慣のためか病歴の取り方が若干簡略的になっていると思われ る方もあり, 逆に, 慢性期診療施設で研修された受験生の中には急性期診療の経験不足が疑われる受験生も いたとの指摘もあり，研修は幅広くおこなうように心がけて頂きたいと考えます，当該研修施設での研修に おいて十分でない領域については，他施設での研修やセミナー・ハンズオンの受講などで補う必要もあり, 広範囲の神経内科研修を心掛けて頂きたい。教科書的な知識のみならず, 広範囲の経験が必要で, 研修指導 者にはそのような研修が可能となるように指導と配慮をお願いしたいと考えます。

外来での経験も必要で, 頭痛, めまい, 未梢神経障害など, 外来で遭遇することが多い疾患についての経 験も心がけて頂きたい，神経生理検査などについても，自分自身で経験をして頂きたく，経験症例数のみな らず，検査の意義や結果の解釈などについての理解なども専門医には求められることを認識して頂くよう希 望します。

今回の試験の総括は以上の通りです。次年度以降の受験生の皆さんには, 神経解剖学・生理学・薬理学・ 病理学などの基本的な理解の上に, 症候学や神経診断学, 画像検査, さらには神経治療学を学んで頂くよう に希望します。また，神経診断は問診から始まる点も理解して研修に務めて頂きたいと思います．日常診療 の中で学んでいくと共に, 本試験に向けて臨床神経学全体についての基本を改めて勉強して頂きたいと考え ます，指導医の先生方には，上記の点も踏まえて指導を頂きますよう，お願いしたいと考えます。

2015 年 7 月 28 日

日本神経学会専門医認定委員会

（文責 専門医認定委員会委員長 中島 健二） 